\title{
Susceptibility Status of Bemisia tabaci Biotypes to Pyrethroid Insecticides in North-Eastern Nigeria
}

\author{
Usman Ngamarju Gadzama $^{1}$, Chinweoke Edith Anaso ${ }^{1}$, Joy Mbaya Turaki ${ }^{1}$, Zakariya Dauda ${ }^{2}$ \\ ${ }^{1}$ Department of Biological Sciences, University of Maiduguri, Maiduguri, Nigeria \\ ${ }^{2}$ Department of Crop Protection, University of Maiduguri, Maiduguri, Nigeria
}

Email address:

ugadzama@yahoo.com (U. N. Gadzama)

To cite this article:

Usman Ngamarju Gadzama, Chinweoke Edith Anaso, Joy Mbaya Turaki, Zakariya Dauda. Susceptibility Status of Bemisia tabaci Biotypes to Pyrethroid Insecticides in North-Eastern Nigeria. International Journal of Ecotoxicology and Ecobiology. Vol. 3, No. 1, 2018, pp. 5-10. doi: $10.11648 /$ j.ijee. 20180301.12

Received: December 14, 2017; Accepted: December 28, 2017; Published: January 15, 2018

\begin{abstract}
A study was conducted to assess the effect of treatments with the recommended application rate of $\alpha$ Cypermethrin, Permethrin, Allethrin, Tetramethrin, Cyhalothrin and Deltamethrin pesticides on Bemisia tabaci biotypes. Two localities each were selected from three States of North-eastern Nigeria for sample collections and determination of susceptibility to the insecticides. The localities include Toro and Wuro wasse in Bauchi State, College of Agric farm center (COAG) and Tudun wada in Borno State, Dadin kowa and Kwadon in Gombe State. The insecticides were applied against adult $B$. tabaci using a leaf-dip bioassay. Insect population that survived any of the insecticides after 24 hours post exposures were considered resistance to the insecticide and their biotypes were determined using Polymerase Chain Reaction (PCR). Overall mean mortality response was $88.89 \%, 91.27 \%, 88.09 \%, 96.83 \%, 93.65 \%$, and 96.05 for $\alpha$-Cypermethrin, Permethrin, Allethrin, Tetramethrin, Cyhallothrin and Deltamethrin respectively and all were significantly different from control $(\mathrm{P}<0.05)$. Populations from Kwadon showed high resistant factor to $\alpha$-Cypermethrin, Tetramethrin and Cyahallothrin $(\mathrm{RF}=221.99$, 128.05 and 98.8-folds respectively). All populations displayed significant resistance to Allethrin (RF ranging from7.01-fold in Tudun wada to 78.93-fold in Kwadon. Tetramethrin resistant was followed by Dadin kowa and Tudun wada (RF $=13.43$ and 13.33) respectively and Cyahallothrin resistant was followed by population from Dadin kowa ( $\mathrm{RF}=82.94$-folds) while Deltamethrin resistant was found to be insignificant between almost all locations. Biotype B exhibited higher resistance for all the evaluated insecticides compared to $\mathrm{Q}$ in all locations.
\end{abstract}

Keywords: Bemisia tabaci, Biotypes, Susceptible, Resistance, Pyrethroids, North-East Nigeria

\section{Introduction}

B. tabaci is among the damaging insect pest of many crops globally. Its population structure is said to be highly cryptic species complex that are morphologically indistinguishable, with 24 described biotypes [16]. It has been shown to transmit 111 virus species, some of which are of high economic importance, causing a significant crop loss. Worldwide, growers routinely use insecticides against $B$. tabaci and these have included broad-spectrum chemicals such as organophosphate, carbornates and pyrethroids. The use of these chemicals for the control of this insect species in the past has shown to have a significant impact on crop production. However, failures to control the pest have been reported recently in many parts of the world probably due to development of insecticide resistance [3]. B. tabaci have shown resistance to over 40 active ingredients of the major synthetic insecticide groups in many countries of world $[8,2$, $1,3]$. Synthetic insecticides therefore if not continuously monitored might not retain its efficacy indefinitely even in areas where resistance have not been reported or investigated. Overdependence on a particular group of chemicals is one of the most important reasons for the rapid development of resistance among insects [5]. Similarly, the over use and increase dosages of insecticides against resistant insect pest populations could lead to disruption of natural enemies of both the target and secondary pest species, thereby generating the notorious "pesticide treadmill" effect. On the other hand, the use of the chemicals pesticides is also 
becoming more problematic in many areas of crop production and insect vector control due to the accumulation effects of these pesticides on human health and the environment. In lieu of this therefore, there is an urgent need for routine monitoring of the efficacy of recommended pesticides that are in use for control of pests. The aim of this study was to evaluate whether populations of B. tabaci from north-east arid zone of Nigeria were susceptible to commonly used pyrethroid insecticides to control pest in the region.

\section{Materials and Methods}

\subsection{Study Area}

The study was conducted in three States of the SudanoSahelian ecological zone of north-east,

Nigeria viz: Bauchi, Borno and Gombe States. In each State, two major areas of farming activities were selected viz: Wuro wasse and Toro (Bauchi); Tudun wada and COAG farms (Borno); and Kwadon and Dadin kowa (Gombe).

Bauchi is the Capital city of Bauchi State and is located in the Sudan-Savannah region of north-east Nigeria at Latitude $10^{\circ} 18^{\prime} \mathrm{N}$ and Longitude $9^{\circ} 50^{\prime} \mathrm{E}$. Gombe on the other hand is the capital city of Gombe State and is located at Latitude $10^{\circ} 17^{\prime} \mathrm{N}$ and Longitude $11^{\circ} 10^{\prime} \mathrm{E}$ while Maiduguri is the Capital city of Borno State and is located in the Sahel Savannah region of North-East Nigeria at Latitude $11^{\circ} 55^{\prime} \mathrm{N}$ and Longitude $13^{\circ} 05^{\prime} \mathrm{E}$ and at about $350 \mathrm{~m}$ above sea level [7]. The weather condition for the three States varies with time and location of an area. In Bauchi for instance the mean daily maximum temperatures range from $29.2^{\circ} \mathrm{C}$ in July and August to $37.6^{\circ} \mathrm{C}$ in March and April. While in Gombe temperature ranges between 22 and $34^{\circ} \mathrm{C}$ and has similar pattern of monthly distribution like Bauchi. In Maiduguri, the rainy season months are May to September with its peak in August. Humidity ranges from about 28 per cent to 46 per cent. Monthly rainfall ranges from $0.0 \mathrm{~mm}$ in December April, to about $343 \mathrm{~mm}$ in August. Onset of the rains varies but more often in April while they end virtually by October. The sunshine hours range from about 5.1 hours in July September to about 10-12 hours in the remaining months [7].

\subsection{Field Collection of Sample for Pyrethroid Susceptibility Test}

B. tabaci were sampled randomly from cotton (Gossypium hirsutum) and tomato (Solanum lycopersicum) plant hosts in six locations that constituted the study area using modified plastic vials by vacuuming plant foliage with a Makita ${ }^{\circledR}$ Cordless Vacuum (Model 4071D) and custom made battery operated suction sampler [6]. Sampling for the whitefly was performed for 2 hours for each sample day from 6: $00-7: 00$ am and 5:00 - 6:00 pm on monthly bases for six months. In each sample location, two sunken beds $10 \mathrm{~m}$ by $20 \mathrm{~m}$ were prepared side by side $100 \mathrm{~m}$ away from farmers planting fields to avoid being sprayed with insecticides during routine farm spray. On each side of bed was planted tomato and cotton respectively for sampling of the whitefly for the study.

\subsection{Bioassay Procedure and Biotype Determination}

Three concentrations $(0.25 \mu \mathrm{g} / \mathrm{ml}, 0.75 \mu \mathrm{g} / \mathrm{ml}$ and 1.00 $\mu \mathrm{g} / \mathrm{ml}$ ) of each of Cypermethrin, Permethrin, Allethrin, Tetramethrin, Cyhallothrin and Deltamethrin insecticides were tested as treatments for the control of B. tabaci following the manufacturer's recommendations. Formulations of test compounds were prepared in distilled water as parts per millions of active ingredients. All the insecticides were tested using a leaf-dip bioassay [17, 11]. Briefly, six leaves were obtained from seedlings of tomato plants measuring between $15-20 \mathrm{~cm}$ tall. Each leaf was dipped into each of the aqueous concentrations of each of the insecticides listed above for fifteen seconds and were allowed to air dry on a paper towel and then placed into petri dishes containing moistened filter papers to avoid desiccation of leaves as described by [9] and one, (untreated control), was dipped into deionized water, and also allowed to air dry for fifteen seconds. Seven adults of B. tabaci from each sample site were released into each petri dish containing the treatment leaves per concentration. Each treatment was replicated 3 times for each set of experiment for each concentration per location along with an untreated control under complete randomized design. Each set of experiment was further replicated three times throughout the study. Knock down resistance (KDR) for an insect sample was recorded at time intervals of 10 minutes for 1 hour while mortality was recorded at 24 hours post exposure treatment. Insects were considered dead after 24 hours when such insects no longer able to move wholly or partially on the treatment leaves. Insect population that showed resistance to any of the insecticides after 24 hour exposures were isolated and subjected to PCR for biotype identification by Random Amplified-length Polymorphism DNA (RAPD) $[4,16,12,14,18]$ using esterase markers.

\subsection{Data Analysis}

Mortality data were analyzed using the Two-Way Analysis of Variance and significant means were differentiated by the Duncan Multiple Mean (DMRT) Comparison using the SPSS, (2004) version.

\section{Results}

\subsection{Susceptibility to a-Cypermethrin Insecticide}

Of the total 126 white flies assayed for each concentration across the study locations, the overall mean mortality for the control, $0.25 \mu \mathrm{g} / \mathrm{l}, 0.75 \mu \mathrm{g} / \mathrm{l}$ and $1.00 \mu \mathrm{g} / \mathrm{l}$ were $7.94 \%$, $57.14 \%, 69.05$ and $88.89 \%$ respectively, (Table 1). Samples collected from Toro and Wuro wasse Farm (Bauchi State) and COAG farm in Borno State were found to be susceptible to $\alpha$-Cypermethrin at the highest recommended dose of 1.00 $\mu \mathrm{g} / \mathrm{l}$ (Mortality $>95 \%$ ), however $\alpha$-Cypermethrin resistance was slightly observed in Tudun wada (Mortality $=90.47$ ) and higher resistance was detected in Whitefly population from Kwadon and Dadin kowa (Mortality $=71.43$ and 80.95 respectively). The overall mean percentage mortality of 
88.89 indicated that B. tabaci within the study areas have developed resistance to $\alpha$-Cypermethrin.

Table 1. \% Mean \pm S. D mortality response of B. tabaci to ( $\alpha$-Cypermethrin.

\begin{tabular}{|c|c|c|c|c|c|}
\hline & & Concentration & & & \\
\hline Samplelocation & Control & $0.25 \mu \mathrm{g} / \mathrm{l}$ & $0.75 \mu \mathrm{g} / \mathrm{l}$ & $1.00 \mu \mathrm{g} / \mathrm{l}$ & RF \\
\hline Toro & $14.29 \pm 5.40^{\mathrm{a}}$ & $57.14 \pm 5.63^{\mathrm{a}}$ & $75.23 \pm 2.66^{\mathrm{a}}$ & $95.23 \pm 2.63^{\mathrm{a}}$ & 0.33 \\
\hline Wuro wasse & $0.00 \pm 0.00^{b}$ & $42.86 \pm 5.80^{\mathrm{b}}$ & $68.23 \pm 3.82^{\mathrm{a}}$ & $95.23 \pm 3.80^{\mathrm{a}}$ & 3.82 \\
\hline Tudun wada & $19.05 \pm 6.77^{\mathrm{a}}$ & $66.67 \pm 3.64^{\mathrm{c}}$ & $70.47 \pm 3.21^{\mathrm{a}}$ & $90.47 \pm 3.12^{\mathrm{b}}$ & 68.82 \\
\hline COAG & $4.76 \pm 5.83^{\mathrm{c}}$ & $76.9 \pm 1.67^{\mathrm{e}}$ & $80.00 \pm 0.58^{b}$ & $100 \pm 0.00^{\mathrm{c}}$ & \\
\hline Kwadon & $9.50 \pm 3.92^{\mathrm{c}}$ & $42.86 \pm 3.66^{\mathrm{b}}$ & $51.43 \pm 2.53^{\mathrm{c}}$ & $71.43 \pm 1.63^{\mathrm{d}}$ & 221.99 \\
\hline Dadin kowa & $0.00 \pm 0.00^{\mathrm{b}}$ & $57.14 \pm 8.88^{\mathrm{a}}$ & $68.95 \pm 4.89^{\mathrm{a}}$ & $80.95 \pm 5.88^{\mathrm{e}}$ & 111.83 \\
\hline$N$ & 126 & 126 & 126 & 126 & \\
\hline Mean & $7.94 \pm 3.22$ & $57.14 \pm 11.2$ & $69.05 \pm 4.76$ & $88.89 \pm 0.42$ & \\
\hline
\end{tabular}

Mortality $<95 \%$ for $1.00 \mu \mathrm{g} / \mathrm{l}$ is resistance to $\alpha$-Cypermethrin, Means in the column with the same letters are not significantly different at $\mathrm{P}=0.05 \mathrm{using}$ DMRT.

\subsection{Susceptibility to Permethrin Insecticide}

The overall mean mortality for the control, $0.25 \mu \mathrm{g} / 1,0.75$ $\mu \mathrm{g} / \mathrm{l}$ and $1.00 \mu \mathrm{g} / \mathrm{l}$ were $6.35 \pm 3.22,57.94 \pm 11.2,79.69 \pm 4.52$, $91.27 \pm 0.42$ respectively, (Table 2). The detail results shown in table 2 indicated that, B. tabaci population collected from Wuro wasse, COAG farm and Tudun wada exhibited absolute susceptibility to Permethrin at field recommended diagnostic concentration of $1.00 \mu \mathrm{g} / \mathrm{l}$ (mortality $=100 \%)$. Kwadon and Dadin kowa population showed resistance to field recommended concentration of 1.00 (mean mortality $=76.19 \%$ and $71.43 \%$ respectively). The overall mean mortality of 91.27 $(<95 \%)$ also indicates permethrin resistance.

Table 2.\% mean \pm S. D Mortality response of B. tabaci to Permethrin.

\begin{tabular}{|c|c|c|c|c|c|}
\hline \multirow[b]{2}{*}{ Sample location } & \multirow[b]{2}{*}{ Control } & \multicolumn{4}{|c|}{ Concentration } \\
\hline & & $0.25 \mu \mathrm{g} / \mathrm{l}$ & $0.75 \mu \mathrm{g} / \mathrm{l}$ & $1.00 \mu \mathrm{g} / \mathrm{l}$ & RF \\
\hline Toro & $14.29 \pm 5.40^{\mathrm{a}}$ & $71.43 \pm 5.63^{\mathrm{a}}$ & $75.23 \pm 4.18^{\mathrm{a}}$ & $95.23 \pm 4.11^{\mathrm{a}}$ & 39.62 \\
\hline Wuro wasse & $0.00 \pm 0.00^{\mathrm{b}}$ & $42.86 \pm 5.80^{\mathrm{b}}$ & $80.00 \pm 5.62^{\mathrm{ab}}$ & $100 \pm 0.00^{\mathrm{b}}$ & $*$ \\
\hline Tudun wada & $9.50 \pm 4.71^{b}$ & $66.67 \pm 3.64^{\mathrm{a}}$ & $71.43 \pm 3.02^{\mathrm{a}}$ & $100 \pm 0.00^{\mathrm{b}}$ & $*$ \\
\hline COAG & $4.76 \pm 5.83^{c}$ & $76.9 \pm 1.67^{\mathrm{a}}$ & $89.44 \pm 5.32^{b}$ & $100 \pm 0.00^{\mathrm{b}}$ & $*$ \\
\hline Kwadon & $9.50 \pm 3.92^{b}$ & $42.86 \pm 3.66^{\mathrm{b}}$ & $73.19 \pm 2.64^{\mathrm{a}}$ & $76.19 \pm 2.68^{c}$ & 135.05 \\
\hline$N$ & 126 & 126 & 126 & 126 & \\
\hline Mean & $6.35 \pm 3.22$ & $57.94 \pm 11.2$ & $79.69 \pm 4.52$ & $91.27 \pm 0.42$ & \\
\hline
\end{tabular}

Mortality $<95 \%$ for 1.00 is resistance to Permethrin, Means in the column with the same letters are not significantly different at P $=0.05$ by DMRT.

\subsection{Susceptibility to Allethrin}

The results of Susceptibility status of Bemisia tabaci to Allethrin insecticide at three diagnostic concentrations is presented in table 3 . As indicated the overall mean mortality at concentration $0.25 \mu \mathrm{g} / \mathrm{l}, 0.75 \mu \mathrm{g} / \mathrm{l}$ and $1.00 \mu \mathrm{g} / \mathrm{l}$ are $60.32 \%, 72.22 \%$ and $88.09 \%$ respectively (Table 3 ). The range mortality for each concentration was $42.86-76.19 \%$,
$61.90-80.95 \%$ and $80.95-100 \%$ respectively across the study sites. Samples collected from Tudun wada farm and Dadin kowa were susceptible to Allethrin (mortality $>95 \%$ ), however, the overall mean of $88.09 \%$ mortality which is < $95 \%$ signifies that the generality of the white flies are not susceptible to Allethrin.

Table 3. \% Mean \pm S. D. mortality response of B. tabaci to Allethrin.

\begin{tabular}{|c|c|c|c|c|c|}
\hline & & Concentration & & & \\
\hline Sample location & Control & $0.25 \mu \mathrm{g} / \mathrm{l}$ & $0.75 \mu \mathrm{g} / \mathrm{I}$ & $1.00 \mu \mathrm{g} / \mathrm{I}$ & $\mathbf{R F}$ \\
\hline Toro & $4.76 \pm 3.20^{\mathrm{a}}$ & $66.67 \pm 6.02^{\mathrm{a}}$ & $71.42 \pm 4.62^{\mathrm{a}}$ & $90.47 \pm 5.63^{\mathrm{a}}$ & 72.06 \\
\hline Wuro wasse & $19.05 \pm 5.56^{\mathrm{b}}$ & $47.62 \pm 7.23^{\mathrm{b}}$ & $66.67 \pm 4.58^{\mathrm{b}}$ & $85.71 \pm 4.57^{\mathrm{ab}}$ & 10.03 \\
\hline Tudun wada & $0.00 \pm 0.00^{\mathrm{c}}$ & $76.19 \pm 6.84^{\mathrm{c}}$ & $76.19 \pm 3.62^{\mathrm{a}}$ & $95.23 \pm 3.33^{\mathrm{a}}$ & 7.01 \\
\hline COAG & $9.52 \pm 2.58^{\mathrm{a}}$ & $61.90 \pm 9.63^{\mathrm{a}}$ & $76.19 \pm 7.22^{\mathrm{a}}$ & $76.19 \pm 8.23^{c}$ & 26.73 \\
\hline Kwadon & $14.29 \pm 3.65^{b}$ & $42.86 \pm 7.78^{b}$ & $61.90 \pm 2.61^{\mathrm{b}}$ & $80.95 \pm 2.89^{d}$ & 78.93 \\
\hline Dadin kowa & $0.00 \pm 0.00^{\mathrm{c}}$ & $66.67 \pm 9.54^{\mathrm{a}}$ & $80.95 \pm 3.02^{\mathrm{c}}$ & $100 \pm 0.00^{\mathrm{e}}$ & $*$ \\
\hline$N$ & 126 & 126 & 126 & 126 & \\
\hline Mean & $7.93 \pm 6.67$ & $60.32 \pm 12.1$ & $72.22 \pm 3.33$ & $88.09 \pm 10.6$ & \\
\hline
\end{tabular}

Mortality $<95 \%$ for 1.00 is resistance to Allethrin, Means in the column with the same letters are not significantly different at $\mathrm{P}=0.05$ by DMRT.

\subsection{Susceptibility to Tetramethrin}

With the exception of population collected from Kwadon which exhibited high resistance where only $66.67 \%$ mortality was 
recorded, all other population exhibited high susceptibility to tetramethrin. The overall mean mortality of $96.83 \%$ recorded against tetramethrin at $1 \mu \mathrm{g} / \mathrm{l}$ indicated that the overall population was susceptible to the insecticide. White flies from Toro, Wuro wasse and COAG farms had no detectable resistance to tetramethrin (mortality $=100 \%)($ Table 4$)$.

Table 4. $\%$ Mean \pm S. D mortality response of B. tabaci to tetramethrin.

\begin{tabular}{|c|c|c|c|c|c|}
\hline \multicolumn{6}{|c|}{ Concentration } \\
\hline Sample location & Control & $0.25 \mu \mathrm{g} / \mathrm{l}$ & $0.75 \mu \mathrm{g} / \mathrm{l}$ & $1.00 \mu \mathrm{g} / \mathrm{l}$ & RF \\
\hline Toro & $9.52 \pm 2.76^{\mathrm{a}}$ & $47.62 \pm 4.40^{\mathrm{a}}$ & $77.15 \pm 4.81^{\mathrm{a}}$ & $100 \pm 0.00^{\mathrm{a}}$ & $*$ \\
\hline Wuro wasse & $0.00 \pm 0.00^{\mathrm{b}}$ & $66.67 \pm 2.56^{b}$ & $66.67 \pm 2.91^{b}$ & $100 \pm 0.00^{\mathrm{a}}$ & $*$ \\
\hline Tudun wada & $9.52 \pm 3.26^{\mathrm{a}}$ & $57.14 \pm 2.52^{\mathrm{c}}$ & $76.19 \pm 2.50^{\mathrm{a}}$ & $95.23 \pm 2.36^{\mathrm{a}}$ & 13.33 \\
\hline COAG & $0.00 \pm 1.50^{\mathrm{b}}$ & $71.43 \pm 7.08^{b}$ & $71.43 \pm 7.04^{b}$ & $100 \pm 1.39^{\mathrm{a}}$ & 78.01 \\
\hline Kwadon & $4.76 \pm 6.22^{\mathrm{a}}$ & $33.33 \pm 5.75^{\mathrm{d}}$ & $52.38 \pm 5.89^{c}$ & $66.67 \pm 4.76^{b}$ & 128.05 \\
\hline Dadin kowa & $0.00 \pm 0.00^{\mathrm{b}}$ & $52.38 \pm 9.78^{\mathrm{c}}$ & $52.38 \pm 13.70^{\mathrm{c}}$ & $95.23 \pm 2.08^{\mathrm{a}}$ & 13.43 \\
\hline Mean & $3.97 \pm 1.14$ & $54.76 \pm 14.3$ & $66.03 \pm 5.24$ & $96.83 \pm 0.34$ & \\
\hline
\end{tabular}

Mortality $<95 \%$ for 1.00 is resistance to tetramethrin, Means in the column with the same letters are not significantly different at P $=0.05$ by DMRT.

\subsection{Susceptibility to Cyhallothrin}

Of the total population exposed to each concentration of $0.25 \mu \mathrm{g} / \mathrm{l}, 0.75 \mu \mathrm{g} / \mathrm{l}$ and $1 \mu \mathrm{g} / \mathrm{l}$, the mean mortality for each concentration was $61.91 \%, 65.88 \%$ and $93.65 \%$ respectively. Resistance to Cyhallothrin was observed in population collected from COAG farm and Kwadon (Mortality < 95\%) (Table 5). Population from Toro (Bauchi State) and Tudun wada farm (Borno State) had no detectable resistance to Cyhallothrin insecticides at $1 \mu \mathrm{g} / \mathrm{l}$.

Table 5. \% Mean \pm S. D Mortality response of B. tabaci to Cyhallothrin.

\begin{tabular}{llllll}
\hline & & Concentration & & \\
\hline Sample location & Control & $\mathbf{0 . 2 5} \boldsymbol{\mu \mathbf { g } / \mathbf { l }}$ & $\mathbf{0 . 7 5} \boldsymbol{\mu \mathbf { g } / \mathbf { l }}$ & $\mathbf{1 . 0 0} \boldsymbol{\mu \mathbf { g } / \mathbf { l }}$ & $\mathbf{R F}$ \\
\hline Toro & $19.05 \pm 1.03^{\mathrm{a}}$ & $61.91 \pm 12.14^{\mathrm{a}}$ & $66.67 \pm 12.00^{\mathrm{a}}$ & $100 \pm 0.00^{\mathrm{a}}$ & $*$ \\
Wuro wasse & $9.52 \pm 7.43^{\mathrm{b}}$ & $76.19 \pm 11.33^{\mathrm{b}}$ & $66.67 \pm 11.46^{\mathrm{a}}$ & $95.24 \pm 3.20^{\mathrm{b}}$ & 0.03 \\
Tudun wada & $0.00 \pm 0.00^{\mathrm{c}}$ & $52.38 \pm 12.63^{\mathrm{c}}$ & $76.19 \pm 11.60^{\mathrm{b}}$ & $100 \pm 0.00^{\mathrm{a}}$ & 0.04 \\
COAG & $4.76 \pm 6.06^{\mathrm{d}}$ & $66.67 \pm 6.68^{\mathrm{a}}$ & $66.67 \pm 6.62^{\mathrm{a}}$ & $90.48 \pm 2.56^{\mathrm{c}}$ & 28.52 \\
Kwadon & $19.05 \pm 2.88^{\mathrm{a}}$ & $47.62 \pm 10.10^{\mathrm{d}}$ & $52.38 \pm 11.08^{\mathrm{c}}$ & $80.92 \pm 1.99^{\mathrm{d}}$ & 98.8 \\
Dadin kowa & $23.81 \pm 5.61^{\mathrm{a}}$ & $66.67 \pm 13.25^{\mathrm{a}}$ & $66.67 \pm 17.20^{\mathrm{a}}$ & $95.24 \pm 3.14^{\mathrm{b}}$ & 82.94 \\
$N$ & 126 & 126 & 126 & 126 & $93.65 \pm 11.65$ \\
Mean & $12.69 \pm 8.61$ & $61.91 \pm 19.3$ & $65.88 \pm 8.58$ & & \\
\hline
\end{tabular}

Mortality $<95 \%$ for $1.00 \mu \mathrm{g} / \mathrm{l}$ is resistance to Cyhallothrin, Means in the column with the same letters are not significantly different at $\mathrm{P}=0.05$ by DMRT.

\subsection{Susceptibility to Deltamethrin}

The results revealed that only Kwadon populations showed resistance to Deltamethrin insecticide at recommended concentration of $1 \mu \mathrm{g} / \mathrm{l} .85 .71 \%$ of the total population exposed died of Deltamethrin which indicated resistance (mortality $<95 \%$ ). On the contrary population from Wuro wasse farm, COAG farm, and Dadin kowa had no detectable resistance (mortality $=100 \%)$ to Deltamethrin (Table 6$)$.

Table 6. \% Mean \pm S. D Mortality response of B. tabaci collected to Deltamethrin.

\begin{tabular}{|c|c|c|c|c|c|}
\hline & & Concentration & & & \\
\hline Sample location & Control & $0.25 \mu \mathrm{g} / \mathrm{l}$ & $0.75 \mu \mathrm{g} / \mathrm{l}$ & $1.00 \mu \mathrm{g} / \mathrm{l}$ & RF \\
\hline Toro & $0.00 \pm 0.00^{\mathrm{a}}$ & $52.38 \pm 13.00^{\mathrm{a}}$ & $90.58 \pm 4.82^{a}$ & $95.24 \pm 4.11^{\mathrm{a}}$ & 34.85 \\
\hline Wuro wasse & $0.00 \pm 0.00^{\mathrm{a}}$ & $71.43 \pm 42.5^{\mathrm{b}}$ & $90.58 \pm 4.04^{\mathrm{a}}$ & $100 \pm 0.00^{\mathrm{b}}$ & 0.05 \\
\hline Tudun Wada & $0.00 \pm 0.00^{\mathrm{a}}$ & $80.95 \pm 10.5^{c}$ & $95.24 \pm 2.81^{\mathrm{b}}$ & $95.24 \pm 2.81^{\mathrm{a}}$ & 40.30 \\
\hline COAG & $9.52 \pm 3.78^{b}$ & $47.62 \pm 11.8^{\mathrm{d}}$ & $100 \pm 0.00^{c}$ & $100 \pm 0.00^{\mathrm{b}}$ & 89.50 \\
\hline Kwadon & $4.76 \pm 5.56^{\mathrm{b}}$ & $80.95 \pm 11.5^{\mathrm{c}}$ & $71.43 \pm 5.29^{d}$ & $85.71 \pm 0.07^{\mathrm{c}}$ & 132.82 \\
\hline Dadin kowa & $9.52 \pm 3.61^{b}$ & $61.91 \pm 25.2^{\mathrm{e}}$ & $80.95 \pm 3.42^{\mathrm{e}}$ & $100 \pm 0.00^{\mathrm{b}}$ & 0.02 \\
\hline Mean & $7.60 \pm 7.40$ & $65.87 \pm 19.6$ & $88.13 \pm 6.32$ & $96.03 \pm 4.06$ & \\
\hline
\end{tabular}

Mortality $<95 \%$ for $1.00 \mu \mathrm{g} / 1$ is resistance to Deltamethrin, Means in the column with the same letters are not significantly different at $\mathrm{P}=0.05$ by DMRT.

\subsection{Comparative Susceptibility Between Population Biotypes}

Of the total $756 \mathrm{~B}$. tabaci analyzed for susceptibility, the frequency distribution of resistance population between biotypes is presented in table 7 
Table 7. Table showing the frequency distribution of resistance among whitefly biotypes.

\begin{tabular}{llllll}
\hline & & & \% frequency of resistance by Biotypes & Unknown \\
\hline Insecticide & No. tested & \% resistance & B & Q & 12.5 \\
\hline$\alpha$-Cypt & 126 & 12.69 & 50.00 & 37.50 & 8.33 \\
Permt & 126 & 9.52 & 50.00 & 41.66 & 6.66 \\
Allt & 11.91 & 60.00 & 33.33 & 11.11 \\
Tetm & 126 & 7.14 & 66.66 & 22.22 & 10.00 \\
Cyht & 126 & 7.94 & 80.10 & 10.00 & 0.00 \\
Delt & 1.59 & 80.00 & 40.00 & 8.10 \\
mean & 126 & 8.47 & 61.13 & 30.79 & \\
\hline
\end{tabular}

Values in brackets are percentage resistance, $\alpha$-Cypt $=\alpha$-Cypermethrin, Permt $=$ permethrin, Allt $=$ Allethrin, Tetm $=$ Tetramethrin, Cyht $=$ Cyhalothrin, Delt=Deltamethrin.

Table 7 above revealed that $B$. tabaci resistance to $\alpha$ Cypermethrin was found to be marginally higher (12.69\%) population, followed by permethrin, Allethrin and the least was resistance to Deltamethrin (1.59\%). Similarly, Biotype B exhibited higher resistance $(>50 \%)$ for all the evaluated insecticides, followed by biotype Q and UK in that order.

\section{Discussion}

This study has revealed variation in the level of insecticide resistance in $B$. tabaci collected in cultivated fields of some parts Bauchi, Borno and Gombe states all located in the Sudan Savannah Ecological Zone of Notheasten Nigeria. The susceptibility status varies with location and biotypes. Generally, the population collected from Kwadon in Gombe State showed a high resistance to all the evaluated insecticide at average recommended field application (ARFA) $(1 \mu \mathrm{g} / \mathrm{l})$ mortality $<95 \%$ as compared to standard recommended percentage mortality $(\geq 95 \%)$ for control of insect pest.

Mortality response of $B$. tabaci was highest in Cyahallothrin, Deltamethrin and tetramethrin in all the average recommended field application of $1 \mu \mathrm{g} / 1$ (mean mortality $=93.65 \%, 96.03 \%$ and $96.83 \%$ ) respectively as against Cypermethrin, Permethrin and Allethrin (88.89\%, $91.27 \%$ and $88.09 \%$ ) respectively and is significantly different $(\mathrm{P}<0.05)$. However, the overall mean performance of all the six pyrethroid insecticides of $92.25 \%$ which is less than recommended standard mortality of $>95 \%$ might be an indication of resistance of the white flies to pyrethroids.

Different levels of resistance were recorded among individual populations from different locations to the different pyrethroid insecticides evaluated. $\alpha$-Cypermethrin resistance was found to be highest in population collected from Kwadon and Dadin kowa in Gombe State $(\mathrm{RF}=221.99$ fold and 111.83) respectively, followed by Tudun wada farm from Borno State $(\mathrm{RF}=168.82$ fold). No detectable resistance to $\alpha$-Cypermethrin was observed in population collected from COAG farm (mortality response was 100\%) (Table 1). Similarly, Permethrin resistance was not detected in population collected from Wuro wasse, Tudun wada and COAG (mortality $=100 \%$ ). However, resistance was observed to be very high in populations collected from Dadin kowa and Kwadon both in Gombe State which exhibited a resistance factor of 248.8 and 135.05 -fold respectively as compared to populations Toro $(\mathrm{RF}=39.62)$.

Evaluation of Allethrin on the Whitefly showed that all populations except Dadin Kowa and Tudun wada displayed significant resistance (mortality $<95 \%$ ) with resistance factor ranging from7.01-fold in Tudun wada farm to 78.93-fold in Kwadon). High slope values $(>4)$ were observed for all whitefly populations from all collection sites, suggesting a high homogeneity of the populations against the Allethrin insecticide. Comparison of resistance of whitefly between biotypes revealed that biotype $\mathrm{B}$ exhibited higher resistance for all the insecticides evaluated and accounted for $>50 \%$ of the total population of whitefly found to be resistance to the insecticides. This result seem to disagree with the report of Nauen and Delnholm [9] who reported higher resistance in Q biotypes compare to B biotypes. However, the differences observed could attribute to variation responses to insecticide active ingredients acting on different target sites [13]. In this study, pyrethroid insecticides were used which targets voltage gated sodium channel of nerve cell membrane [9] as compared to Nauen and Delnholm [15] who used organophosphate and carbomates insecticides which both target acetyl cholinesterase in the nerve cell synapse.

\section{Conclusion}

This study has shown that Bemisia tabaci in north-eastern Nigeria have shown to have developed resistance to pyrethroid insecticides at the recommend dose. The resistance was low to moderate depending on location and biotype. For effective utilization of the evaluated insecticides, there is need for upward review of the recommended concentration. Biotype B exhibited more resistance than Q while population from Gombe State were more resistance to insecticides compare to other locations.

\section{References}

[1] Ahmad M., Arif M. I. and Attique M. R. (1997). Pyrethroid resistance of Helicoverpaarmiger (Lepidoptera: Noctuidae) in Pakistan. Bulletin of Entomological Research, 87: 343-347

[2] Armes N. J., Bond G. S. and Cooter R. J. (1992). Laboratory culture and development of Helicoverpa armigera. Natural Resources Institute, Natural Resources Institute Bulletin 5, Chatham, UK, 22. 
[3] Bues R., Bouvier J. C. and Boudinhon I. (2005). Insecticides resistance and mechanism of resistance to selected strains of Helicoverpa armigera (Lepidoptera: Noctiudae) to Nomuraea rileyi: effect of pathotype, dosage, temperature and host age. Journ. Econ. Entomol., 77: 247- 253

[4] Cervera M. T., J. A. Cabezas B. Simon J. M. Martinez Zapater, F. Beitia and J. L. Cenis, (2000). Genetic relationships among biotypes of Bemisia tabaci (Hemiptera: Aleyrodidae) based on AFLP analysis. Bull. Entomol. Res., 90: 391-396.

[5] Chu D., Wan F. H., Zhang Y. J and Brown J. K. (2010). Change in the biotype composition of Bemisa tabaci in Shandog Province of China. Environ. Entomol., 39: 10281036 .

[6] Dittrich V., Ernst G. H., Ruesh O. and Uk S. (1990). Resistance mechanisms in sweet-potato whitefly (Homoptera: Aleyrodidae) populations from Sudan, Turkey, Guatemala and Nicaragua. Journ. Econ. Entomol. 83:1665-1670.

[7] Department Nigeria Metrological Agency (2013). Report series, 38 .

[8] Gunning R. V., Balfe M. E. and Easton C. S. (1992). Carbamate resistance in Helicoverpa armigera (Hubner) (Lepidoptera: Noctuidae) in Australia. J. Austral. Entomol. Soci. 31: 97-102.

[9] Horowitz A. R., Kontsedalov S., Khansdan V. and Ishaaya I. (2005). Biotype B and Q of Bemisia tabaci and their relevance to neonicotinoid and pyriproxyfen resistance. Arch Insect Biochem Physiol., 58: 216-225.

[10] Horowitz A. R., Breslauer H., Rippa M., Kontsedalov S., Chanim M., Weintraub P. and Ishaaya I. (2014) Dynamic of Biotypes ' $\mathrm{B}$ ' and ' $\mathrm{Q}$ ' of Bemisia tabaci in cotton fields and their relevance to insecticide Resistance. World Cotton Research Conference on Technologies for Prosperity, 232- 238
[11] Li A. Y., Dennehy T. J. and Nichols R. L. ( 2003). Baseline susceptibility and development of resistance to pyriproxyfen in Bemisia argentifolii (Homoptera: Aleyrodidae) in Arizona. J. Econ. Entomol. 96: 1307-1314.

[12] Lima L. H. C., D. Navia, P. W. Inglis and M. R. V. De Oliveira (2000). Survey of Bemisia tabaci (Gennadius) (Hemiptera: Aleyrodidae) biotypes in Brazil using RAPD markers. Genet. Mol. Biol., 23: 781-785.

[13] McCaffery A. and Nauen R. (2006). The Insecticide Resistance Action Committee (IRAC): Public responsibility and enlightened industrial self-interest. Outlooks on Pest Management 2: 11-14.

[14] Moya A., P. Guirao, D. Cifuentis, F. Beitia and J. L. Cenis (2001). Genetic diversity of Iberian populations of Bemisia tabaci (Hemiptera: Aleyrodidae) based on random amplified polymorphic DNA-polymerase chain reaction. Mol. Ecol., 10: 891-897.

[15] Nauen and Denholm I. (2005). Resistance of insect pests to neonicotinoid insecticides: current status and future prospects. Arch. Insect Biochem. Physiol. 58: 200-215.

[16] Perring T. M. (2001). The Bemisia tabaci species complex. Crop protec. 20: 725-737.

[17] Prabhaker N., Toscano N. C., Castle S. J. and Henneberry T. J. (1997). Selection for imidacloprid resistance in silver leaf whiteflies from the Imperial Valley and development of a hydroponic bioassay for resistance monitoring. Pesticide Science 51: 419-428.

[18] Tsagkarakou A. and N. Roditakis (2003). Isolation and characterization of microsatellite loci in Bemisia tabaci (Hemiptera: Aleyrodidae), Mol. Ecol. Notes, 3: 196-198. 